\title{
Árangur aðgerða við ósæðargúlp í rishluta ósæðar á Íslandi 2000-2014
}

\author{
Helga Björk Brynjarsdóttir ${ }^{1}$ læknanemi, Inga Hlíf Melvinsdóttir ${ }^{2}$ læknir, Tómas Guð̋bjartsson ${ }^{1,3}$ læknir, \\ Arnar Geirsson ${ }^{3} \longmapsto k$ nir
}

\section{Á G R I P}

Inngangur: Osæđargúlpur í brjóstholi er frekar sjaldgæfur sjúkdómur par sem meðferð er flókin og fylgikvillar algengir. Tilgangur rannsóknarinnar var að̋ kanna árangur skurðaðgerða við ósæðargúlpum á íslandi með tilliti til snemmkominna fylgikvilla, 30 daga dánartíoni og langtímalifunar, en slík rannsókn hefur ekki verið gerð áđur á Íslandi.

Efniviður og aðferðir: Afturskyggn rannsókn á 105 sjúklingum (meðalaldur 60,7 ár, 69,5\% karlar) sem gengust undir aðgerð vegna ósæðargúlps í rishluta ósæðar á Landspítala frá 1. janúar 2000 til 31. desember 2014. Sjúklingar með áverka á ósæð eða bráða ósæðarflysjun (acute aortic dissection) voru útilokaðir. Upplýsingar fengust úr sjúkraskrám og voru skráđar ýmsar klínískar breytur, aðgerðartengdir pættir og fylgikvillar. Heildarlifun var reiknuð með aðferð Kaplan-Meier og var meðaleftirfylgdartími 5,7 ár.
Niðurstöður: Alls höfðu 52 sjúklingar (51,0\%) tvíblöðku-ósæðarloku og 10 $(9,5 \%)$ höfðu fjölskyldusögu um ósæðargúlp. Helmingur sjúklinga (50,5\%) var einkennalaus. Algengasta tegund aðgerðar var ósæðarrótarskipti með lífrænni loku. Tveir priðju sjúklinga fengu fylgikvilla og voru peir alvarlegir í $31,4 \%$ tilfella. Heilablóðfall greindist hjá tveimur sjúklingum (1,9\%) en aðrir tveir sjúklingar létust innan 30 daga frá aðgerð $(1,9 \%)$. Lifun einu ári frá aðgerð var $95,1 \%$, og var lifun karla betri en kvenna (97,2\% á móti $90,4 \%$, $p=0,0012$, log-rank próf) en 5 ára lifun var $90,3 \%$.

Ályktanir: Árangur skurðaðgerða við ósæðargúlp í rishluta ósæðar á Íslandi er sambærilegur við erlendar rannsóknir. Fylgikvillar eru tíðir pótt tíðni heilablóðfalls sé lág, eins og 30 daga dánartíðni. Langtímalifun er gód, en lifun karla er betri en kvenna.

\section{Inngangur}

Ósæðargúlpur í brjóstholshluta ósæðar (thoracic aortic aneurysm) er tiltölulega sjaldgæfur sjúkdómur par sem pvermál ósæðar er aukið um að minnsta kosti 50\% miðað við eðlilega vídd ósæðar. ${ }^{1}$ Nýgengi samkvæmt erlendum rannsóknum er talið vera á bilinu 6-10 tilfelli/100.000/ári. Sú staðreynd að flestir sjúklingar eru einkennalausir gerir nákvæmt mat á nýgengi erfiðara. ${ }^{2}$ Orsök gúlpmyndunar í ósæð er ekki að fullu pekkt en hrörnun á miðlagi hennar virðist vega pungt í sjúkdómsferlinu. Ójafnvægi á myndun og niðurbroti millifrumuefnis veikir miðlag æðaveggsins sem veldur penslu og gúlpmyndun.,3 Bandvefssjúkdómar eins og heilkenni Marfans eða heilkenni Ehler Danlos og tvíblöðku-ósæðarloka auka líkur á myndun ósæðargúlps. Háprýstingur er einnig pekktur áhættupáttur. ${ }^{5}$ Erfðarannsóknir hafa leitt í ljós ýmis tengsl við ósæðargúlpa og lýst hefur verið stökkbreytingum sem koma fram í fjölskyldum. Í heildina eru ættgengir ósæðargúlpar taldir skýra um $20 \%$ sjúkdómstilfella. ${ }^{6-8}$

Algengustu einkenni ósæðargúlps eru brjóst- eða bakverkir og einkenni hjartabilunar pegar ósæðarlokan er lek. ${ }^{9}$ Oftar en ekki eru sjúklingar pó án einnkenna og greinast fyrir tilviljun.

'Læknadeild Háskóla Íslands, ${ }^{2}$ Landspítalinn, ${ }^{3}$ hjarta- og lungnaskurðdeild Landspítala. Fyrirspurnum svarar Arnar Geirsson arnarge@landspitali.is

Höfundar hafa útfyllt eyðublað um hagsmunatengsl.

https://doi.org/10.17992//bl.2016.12.111
Tilviljanagreiningum hefur fjölgað á Vesturlöndum samhliða fjölgun myndrannsókna vegna óskyldra sjúkdóma í brjóstholi, til dæmis við leit að æxlum í lungum eða við tölvusneiðmyndatöku á kransæðum. ${ }^{10}$

Ef rof eða flysjun (dissection) verður á gúlpnum er 30 daga dánarhlutfall allt að $25 \%$ hjá peim sem ná lifandi í aðgerð, en rof er jafnframt langalvarlegasti fylgikvilli sjúkdómsins. ${ }^{11,12}$ Pví er reynt að gera skurðaðgerð á æðargúlp áður en hann rofnar. Hætta á rofi og flysjun eykst við aukið pvermál ósæðarinnar. Ef pvermálið er $6 \mathrm{~cm}$ er árleg tíðni rofs eða flysjunar í kringum $14 \%{ }^{13}$ Algengasta viðmið fyrir fyrirbyggjandi skurðaðgerð er pegar pvermál ósæðar er komið yfir 5,5 cm hjá einkennalausum sjúklingum. Oft er miðað við minna pvermál hjá sjúklingum með aðra áhættupætti flysjunar, eins og tvíblöðku-ósæðarloku, pekkta bandvefssjúkdóma eða gúlpa sem stækka ört (>3 mm á ári). ${ }^{13,14}$ Ósæðargúlpar sem valda einkennum eru fjarlægðir með skurðaðgerð, óháð stærð.

Markmið pessarar rannsóknar var að kanna árangur skurðaðgerða við ósæðargúlp í rishluta ósæðar á Íslandi en slík rannsókn hefur ekki verið gerð áður hérlendis. Helstu áherslur voru á snemmkomna fylgikvilla, 30 daga dánarhlutfall og langtímalifun.

\section{Efniviður og aðferðir}

Rannsóknin var afturskyggn og náði yfir 15 ára tímabil frá 1. janúar 2000 til 31. desember 2014. Listi yfir sjúklinga var fenginn úr sjúklingabókhaldi Landspítala og var leitað eftir aðgerðakóðum fyrir ósæðarrótarskipti, viðgerð á ósæð og aðgerðir par sem hjarta- og lungnavél var notuð með blóðrásarstöðvun í djúpri kæl- 
ingu. Alls gengust 105 sjúklingar undir aðgerð við ósæðargúlp í rishluta ósæðar á tímabilinu og mynduðu peir rannsóknarpýðið. Sjúklingum sem höfðu áverka á ósæð eða bráða ósæðarflysjun (acute aortic dissection) var sleppt en árangur peirra aðgerða á Íslandi hefur áđur verið birtur í Læknablaðinu. ${ }^{12}$

Fyrir hvern sjúkling voru skráðar í rafrænan gagnagrunn rúmlega 100 breytur úr sjúkraskrám. Skráðir voru áhættupættir hjarta- og æðasjúkdóma, saga um útæðasjúkdóm og æðagúlpa, hvort um tvíblöðku-ósæðarloku var að ræða, ósæðarlokuprengsl eða ósæðarlokuleka. Einnig voru skráðir bandvefssjúkdómar eins og Marfans eða Ehler Danlos-heilkenni og fjölskyldusaga um ósæðargúlp. EuroSCORE II var reiknað fyrir alla sjúklinga, en pað er áhættulíkan til að meta dánarlíkur innan 30 daga eftir hjartaskurðaðgerð. ${ }^{15}$ Einnig voru skráð einkenni sem leiddu til greiningar og mesta pvermál ósæðargúlps í cm. Upplýsingar um stærð fengust úr sjúkraskrám og byggðu á mælingum á tölvusneiðmyndum eða hjartaómun. Í vafatilfellum voru myndrannsóknir skoðaðar að nýju.

Úr aðgerðarlýsingum var skráð hvers konar aðgerð var gerð hverju sinni. Tími á hjarta- og lungnavél og æðatengingar voru skráðar, einnig tímalengd blóðrásarstöðvunar og hvort sérstakri heilavernd (cerebral protection) var beitt. Loks var skráð blæðing í brjóstholskera á fyrsta sólarhring eftir aðgerð ásamt notkun blóðhluta í og eftir aðgerð.

Fylgikvillar voru flokkaðir í alvarlega og minniháttar. Útlistun á skráoum fylgikvillum má sjá í töflu III. Upplýsingar um fylgikvilla miðuðust við skráningu í sjúkraskrám. Að auki voru blóðrannsóknir skoðaðar, einkum til að meta bráðan nýrnaskaða og hjartadrep. Bráður nýrnaskaði miðaðist við $\geq 50 \%$ hækkun á S-kreatíníni frá grunngildi sjúklings innan við viku frá aðgerð. pau tilfelli par sem nýrnaskaði var pað alvarlegur að pörf var á skilunarmeðferð voru flokkuð með alvarlegum fylgikvillum. Hjartadrep í og eftir aðgerð (perioperative myocardial infarction) miðaðist CKMB við hæstu mælingu eftir aðgerð $>70 \mu \mathrm{g} / \mathrm{L}$.

\section{Skurðaðgerðir}

Allar aðgerðirnar voru framkvæmdar í gegnum bringubeinsskurð með aðstoð hjarta- og lungnavélar. Slagæðatengingu fyrir hjartaog lungnavél var komið fyrir í rishluta ósæðar, holhandar- og viðbeinsslagæð eða náraslagæð. Aðgerðartækni fór eftir staðsetningu gúlps á ósæðinni og ástandi ósæðarloku (leki eða prengsl) og var alls beitt 6 mismunandi tegundum aðgerða. Ef ósæðarlokan var heil og gúlpurinn náði ekki niður í ósæðarrót var einungis skipt um ósæðina ofan við lokuplanið. Í einu tilviki var í sömu aðgerð fyrst skipt um loku og síðan ósæð ofan við lokuplanið. Ef gúlpurinn náði niður í ósæðarrót og skipta purfti um ósæðarloku voru ýmist notaðar lífrænar eða ólífrænar lokur með samsettum æðagræðlingi ( $g r a f t$ ). Ef talið var mögulegt að gera við lokuna var pað gert með lokusparandi aðgerð (David-aðgerð). Loks voru aðgerðir par sem rishluta ósæðar var ekki skipt út, heldur hún sveipuð með ytra stoðneti (wrapping). Fjartenging (distal anastomosis) var oftast gerð á rishluta ósæðar. Í tilvikum par sem ósæðarbogi var einnig víkkaður var gert við hann með viðgerð á neðri ósæðarboga (hemiarch replacement) og í einu tilviki á öllum ósæðarboga (total arch
Tafla I. Sjúklingatengdir pættir. Fjöldi sjúklinga og hlutfall (\%) eða meðaltal með staðalfráviki. $N=105$.

\begin{tabular}{|c|c|c|}
\hline & Fjöldi & $\%$ \\
\hline Aldur & $60,7 \pm 13,9$ & \\
\hline Karlar & 73 & 69,5 \\
\hline Tvíblöðku-ósæðarloka (n=102)* & 52 & 51 \\
\hline Ósæðarlokuprengs| & 33 & 31,4 \\
\hline Ósæðarlokuleki & 46 & 43,8 \\
\hline Marfans-heilkenni & 5 & 4,8 \\
\hline Háprýstingur & 68 & 64,8 \\
\hline Sykursýki af gerð 2 & 3 & 2,9 \\
\hline Blóðfituröskun & 31 & 29,5 \\
\hline Langvinnur nýrnasjúkdómur & 8 & 7,6 \\
\hline Kransæðasjúkdómur & 8 & 7,6 \\
\hline Áður gerð kransæðavíkkun & 4 & 3,8 \\
\hline Áður gengist undir kransæðahjáveituaðgerð & 1 & 0,95 \\
\hline Útæðasjúkdómur & 4 & 3,8 \\
\hline Saga um ósæðargúlp í kviðarholi & 2 & 1,9 \\
\hline Áður heilablóðfall & 8 & 7,6 \\
\hline Langvinn lungnateppa & 6 & 5,7 \\
\hline Aldrei reykt $(n=101)^{\star \star}$ & 33 & 32,7 \\
\hline Saga um reykingar $(n=101)^{\star \star}$ & 68 & 67,3 \\
\hline $\begin{array}{l}\text { Fjölskyldusaga um ósæðargúlp í brjóst- eða } \\
\text { kviðarholshluta ósæðar }\end{array}$ & 10 & 9,5 \\
\hline Líkamspyngdarstuðull (kg/m²) & $28,1 \pm 5$ & \\
\hline EuroSCORE II & $4,5 \pm 5,7$ & \\
\hline
\end{tabular}

Upplýsingar um tvíblöđku-ósæðarloku vantaði fyrir prjá sjúklinga* og upplýsingar um reykingar vantaði hjá fjórum sjúklingum ${ }^{\star *}$.

replacement). Aðgerðir á ósæðarboga voru yfirleitt gerðar í blóðrásarstöðvun par sem notuð var djúp $\left(14,1-20^{\circ} \mathrm{C}\right)$ eða miðlungsdjúp $\left(20,1-28^{\circ} \mathrm{C}\right)$ kæling og blóði að auki veitt sérstaklega til heilaæða (selective cerebral perfusion) til að varðveita heilastarfsemi. ${ }^{16,17}$

\section{Tölfræði}

Gagnagrunnur var útbúinn í forritinu Microsoft Excel ${ }^{\circledR}$ (Microsoft, Redmond WA) og tölfræðiúrvinnsla gerð í forritinu RStudio ${ }^{\circledR}$. Við samanburð hópa voru notuð t-próf og Fisher's exact próf en log-rank próf við samanburð á lifun sjúklinga. Fjölpátta aðhvarfsgreining var notuð til að meta lifun karla og kvenna óháð aldri, en pað var gert með lifunarlíkani sem innihélt bæði kyn og aldur. Til að meta árlegan fjölda aðgerða var gerð Poisson-aðhvarfsgreining og reiknað gagnlíkindahlutfall (Odds ratio, OR) með 95\% öryggisbili (ÖB). Marktæki miðast við tvíhliða p-gildi $<0,05$. Heildarlifun var reiknuð með aðferð Kaplan-Meier. Dánardagur var skráður samkvæmt upplýsingum úr Sögukerfi Landspítala sem tengt er Dánarmeinaskrá Embættis landlæknis. Eftirlit miðaðist við 1. maí 2015 og var meðaleftirfylgdartími 5,7 ár (miðgildi 6,0 ár, bil: 0,01 $-15,0)$. 
Tafla II. Aðgerðatengdir pættir. Fjöldi sjúklinga og hlutfall (\%) eða meðaltal með staðalfráviki. $\mathrm{N}=105$.

\begin{tabular}{|c|c|c|}
\hline & Fjöldi & $\%$ \\
\hline \multicolumn{3}{|l|}{ Slagæð sem HLV var tengd við } \\
\hline Rishluti ósæðar/ósæðarbogi & 80 & 76,2 \\
\hline Náraslagæð & 14 & 14,3 \\
\hline Holhandar- eða viðbeinsslagæð & 11 & 10,5 \\
\hline \multicolumn{3}{|c|}{ Nærlæg viðgerð á ósæð (proximal anastomosis, n=105) } \\
\hline Rishluti & 23 & 21,9 \\
\hline Rótarskipti, ólífræn loka & 19 & 18,1 \\
\hline Rótarskipti, lífræn loka & 28 & 26,7 \\
\hline Lokusparandi rótarskipti (David-aðgerð) & 16 & 15,2 \\
\hline Lokuskipti + rishluti & 1 & 0,95 \\
\hline Sveipun (wrapping) & 18 & 17,1 \\
\hline \multicolumn{3}{|l|}{ Fjartenging (distal anastomosis, $\mathrm{n}=87$ ) } \\
\hline Rishluti & 76 & 87,4 \\
\hline Neðri ósæðarbogi & 10 & 11,5 \\
\hline Allur ósæðarbogi & 1 & 1,1 \\
\hline \multicolumn{3}{|l|}{ Blóðrásarstöðvun (n=8) } \\
\hline Lengd, mínútur & $17 \pm 10$ & \\
\hline Lægsti líkamshiti ${ }^{\circ} \mathrm{C}$, miðgildi & 24 & \\
\hline Framvirk blóðveita til heila (ACP) & 8 & 100 \\
\hline Tími á hjarta- og lungnavél, mínútur & $166 \pm 63$ & \\
\hline Tangartími, mínútur & $118 \pm 47$ & \\
\hline Kransæðahjáveituaðgerð & 21 & 20 \\
\hline
\end{tabular}

$\mathrm{HLV}=$ hjarta- og lungnavél, $\mathrm{ACP}=$ antegrade cerebral perfusion

Rannsóknin var framkvæmd með tilskildum leyfum frá Vísindasiðanefnd, Persónuvernd og framkvæmdastjóra lækninga á Landspítala.

\section{Niðurstöður}

Helstu lýðfræðilegar upplýsingar um sjúklingana eru sýndar í töflu I. Karlar voru 69,5\% af pýðinu. Meðalaldur sjúklinga á aðgerðardegi var 60,7 $\pm 13,9$ ár (bil: 23-85). Konur voru að meðaltali 3,4 árum eldri en karlar en aldursmunurinn var ekki tölfræðilega marktækur. Alls höfðu 64,8\% sjúklinga sögu um háprýsting og 51,0\% höfðu tvíblöðku-ósæðarloku. Hlutfall tvíblöðkuloku var hærra hjá körlum en konum, eða 59,7\% borið saman við 30,0\% ( $\mathrm{p}=0,012)$. Ósæðarlokuprengsl voru til staðar hjá 33 sjúklingum en 26 peirra höfðu tvíblöðkuloku (78,8\%). Ósæðarlokuleki var til staðar hjá 46 sjúklingum og voru 20 peirra með tvíblöðkuloku (43,5\%). Bæði ósæðarlokuleka- og -prengsl höfðu 10 sjúklingar. Fyrir aðgerð hafði heilkenni Marfans verði greint hjá 5 sjúklingum (4,8\%) en enginn hafði greint Ehler Danlos-heilkenni. Fjölskyldusaga um ósæðargúlpa var til staðar hjá 10 sjúklingum (9,5\%). Meðal EuroSCORE II fyrir allt pýðið var 4,5 \pm 5,7 (bil: 1,0 - 45,5).

Helsta ábending fyrir aðgerð var stærð eða hröð stækkun ósæðargúlps (66,7\%). Par á eftir komu ósæðarlokuprengsl, ósæðar-
Tafla III. Fylgikvillar eftir aðgerð. Fjöldi og hlutfall. N=105.

\begin{tabular}{|c|c|c|}
\hline & Fjöldi & $\%$ \\
\hline Fylgikvillar & 70 & 66,7 \\
\hline Alvarlegir fylgikvillar & 33 & 31,4 \\
\hline Enduraðgerð vegna blæðingar & 15 & 14,3 \\
\hline Hjartadrep* & 16 & 15,2 \\
\hline Barkaraufun (tracheostomy) & 4 & 3,8 \\
\hline Pörf á nýrnaskilun $(n=104)^{\star \star \star}$ & 3 & 2,9 \\
\hline Djúp bringubeinssýking & 0 & 0 \\
\hline Heilablóðfall & 2 & 1,9 \\
\hline Fjölkerfabilun & 2 & 1,9 \\
\hline Minniháttar fylgikvillar & 62 & 59 \\
\hline Nýtilkomið gáttatif/flökt $(n=97)^{\star *}$ & 41 & 42,3 \\
\hline Öndunarvélameðferð >48 klukkustundir & 18 & 17,1 \\
\hline Lungnabólga & 12 & 11,4 \\
\hline Bráđur nýrnaskaði $(n=104)^{\star \star \star}$ & 16 & 15,4 \\
\hline Grunn bringubeinssýking & 6 & 5,7 \\
\hline Aftöppun fleiðruvökva & 16 & 15,2 \\
\hline Aftöppun gollurshússvökva & 13 & 12,4 \\
\hline Dauði í aðgerð & 0 & 0 \\
\hline Dánarhlutfall innan 30 daga (skurðdauði) & 2 & 1,9 \\
\hline \multicolumn{3}{|c|}{$\begin{array}{l}\text { CKMB = kreatín kínasi }>70 \mu \mathrm{g} / \mathrm{L}^{\star} \text {. Sjúklingar sem höfðu sögu um gáttatif/gáttaflökt } \\
\text { voru ekki taldir með til nýtilkomins gáttatifs/gáttaflökts**. Einn sjúklingur var með } \\
\text { lokastigs nýrnabilun fyrir aðgerð og í skilunarmeðferð og var ekki talinn með sem bráður } \\
\text { nýrnaskaði eða pörf á nýrnaskilun }{ }^{\star \star \star} \text {. }\end{array}$} \\
\hline
\end{tabular}

lokuleki eða ef fyrirhuguð var kransæðahjáveituaðgerð. Fleiri en ein ábending fyrir aðgerð var til staðar hjá tveimur priðju sjúklinga $(67,6 \%)$.

Helmingur sjúklinga (50,5\%) var einkennalaus og greindist fyrir tilviljun. Hjartabilun með mæði var til staðar hjá 36 sjúklingum $(34,3 \%)$ og 15 sjúklingar (14,3\%) voru með brjóstverk við greiningu. Einn sjúklingur kvartaði bæði um brjóstverk og mæði.

Meðalstærð ósæðargúlps við greiningu var 55,6 \pm 9,1 mm í mesta pvermál; eða 55,0 \pm 10,7 mm hjá sjúklingum með einkenni sem rekja mátti til gúlpsins og 56,3 \pm 7,3 mm hjá peim sem ekki höfðu einkenni sem rekja mátti til gúlpsins $(\mathrm{p}=0,48)$. Stærsti gúlpurinn var $100 \mathrm{~mm}$ og teygði hann sig niður í ósæðarrót.

Að meðaltali voru gerðar 7 aðgerðir á ári. Aðgerðum fjölgaði marktækt eftir pví sem leið á tímabilið (OR: 1,07, 95\%-ÖB: 1,021,12, p=0,003), eða úr 23 aðgerðum á árunum 2000-2004 í 38 aðgerðir árin 2005-2009 og 44 aðgerðir frá 2010-2014. Engin aðgerð flokkaðist sem bráðaaðgerð en 5 aðgerðir voru gerðar í flýti vegna einkenna sem rakin voru til gúlpsins, oftast vegna brjóstverkja. Í engu tilfellanna reyndist ósæðargúlpur rofinn.

Tafla II sýnir hvaða aðgerðir voru framkvæmdar. Algengust voru ósæðarrótarskipti með lífrænni loku (bioprosthesis), eða í 28 tilfellum. Hjá 18 sjúklingum var ósæðinni ekki skipt út en hún í staðinn sveipuð stoðneti. Gert var við ósæðarbogann hjá 11 sjúklingum og var blóðrásarstöðvun með djúpri kælingu framkvæmd í 8 tilfellum. Var meðaltímalengd blóðrásarstöðvunar $17 \pm 10$ mín og blóði veitt sérstaklega til heilaæða í öllum tilfellum. Hjá 20\% 
Tafla IV. Blæðing fyrsta sólarhringinn eftir aðgerð og notkun blóðhluta. Meðaltal með staðalfráviki og bil innan sviga. $N=105$.

\begin{tabular}{lcc}
\hline & Meðaltal & Bil \\
\hline Blæðing fyrstu 24 klst $(\mathrm{mL})$ & $965 \pm 659$ & $(130-3780)$ \\
\hline Rauðkornapykkni (einingar) & $6,2 \pm 5,7$ & $(0-25)$ \\
\hline Blóðvökvi (einingar) & $8,1 \pm 7,5$ & $(0-38)$ \\
\hline Blóðflögur (sett) & $2,2 \pm 1,6$ & $(0-8)$ \\
\hline
\end{tabular}

sjúklinga var að auki framkvæmd kransæðahjáveituaðgerð í sömu aðgerð.

Fylgikvillar eftir aðgerð eru sýndir í töflu III. Heildartíðni fylgikvilla var $66,7 \%$ og var algengasti fylgikvillinn nýtilkomið gáttatif (42,3\%) Tíðni alvarlegra fylgikvilla var 31,4\% en par reyndust hjartadrep í eða eftir aðgerð $(15,2 \%)$ og enduraðgerð vegna blæðingar (14,3\%) vera efst á blaði. Heilablóðfall í eða eftir aðgerð greindist hjá tveimur sjúklingum (1,9\%). Enginn peirra 8 sjúklinga sem gengust undir blóðrásarstöðvun vegna gúlps á ósæðarboga fékk heilablóðfall. Tveir sjúklingar létust innan 30 daga frá aðgerð $(1,9 \%)$, fjórum og 15 dögum frá aðgerð, og var dánarmein peirra beggja fjöllíffærabilun (multiorgan failure). Reiknað EuroSCORE II fyrir pessa sjúklinga var 9,7 og 5,0.

Blæðing á fyrsta sólarhring eftir aðgerð og notkun blóðhluta er sýnd í töflu IV. Meðalblæðing í brjóstholskera á fyrstu 24 klukkustundum eftir aðgerð var $965 \mathrm{~mL}$ (bil: 130-3780 mL).

Miðgildi legutíma var 10 dagar (bil: 6-84), par af einn sólarhringur á gjörgæsludeild (bil: 1-36). Meðallegutími á sömu deildum voru 14,6 og 3,4 dagar. Ellefu sjúklingar (10,5\%) útskrifuðust heim innan 8 daga frá aðgerð.

Einu, 5 og 10 árum frá aðgerð var lifun 95,1\% (95\%-ÖB: 91,1 - 99,4\%), 90,3\% (95\%-ÖB: 84,5 - 96,6\%) og 81,8\% (95\%-ÖB: 71,6 93,4\%). Lifun karla reyndist marktækt betri en kvenna, eða 97,2\% borið saman við 90,4\% eftir eitt ár og 93,7\% og 83,1\% eftir 5 ár ( $p=0,0012$, log-rank próf). Lifun breyttist ekki marktækt yfir rannsóknartímabilið.

\section{Umræða}

Í pessari rannsókn er í fyrsta skipti á Íslandi lýst árangri af skurðaðgerðum við ósæðargúlp í brjóstholshluta ósæðar, en skurðaðgerð er kjörmeðferð til að fyrirbyggja rof eða flysjun á ósæðinni. Árangur aðgerðanna reyndist góður og sambærilegur við erlendar rannsóknir. ${ }^{18,19}$ Líkt og í peim rannsóknum var meðalaldur sjúklinga í kringum sextugt og næstum tveir af hverjum premur sjúklinganna voru karlar (69,5\%).

Sjúklingahópurinn reyndist nokkuð misleitur í okkar rannsókn. Ábending fyrir aðgerð var ekki einungis bundin við stærð ósæðargúlps heldur voru einnig tilfelli par sem helsta ábending var ósæðarlokuleki vegna víkkunar á ósæðarrót eða ósæðarlokuprengsl. Í fáeinum tilvikum var kransæðasjúkdómur helsta ábending fyrir aðgerð og aðgerð á ósæðargúlp gerð samtímis kransæðahjáveitu. Einkenni sjúklinga gátu verið mjög breytileg, eða allt frá pví að vera alvarleg hjartabilun vegna ósæðarlokuleka en aðrir voru einkennalausir og höfðu greinst fyrir tilviljun. Ekki reyndist marktækur munur á stærð gúlps eftir pví hvort einkenni voru til staðar eða ekki. Allir sjúklingar gengust undir kransæðamyndatöku fyrir aðgerð og var gerð kransæðahjáveita í sömu aðgerð hjá $20 \%$ sjúklinga sem höfðu marktæk prengsl í stærri kransæðagreinum.

Meðalstærð ósæðargúlpanna var 55,6 mm sem samrýmist peim alpjóðlegu leiðbeiningum sem oftast er miðað við sem ábendingu fyrir aðgerð. Pannig er miðað við 55 mm í leiðbeiningum Evrópsku hjartalæknasamtakanna (European Society of Cardiology) frá 2014 hjá einkennalausum sjúklingum sem ekki hafa sögu um bandvefssjúkdóm eins og Marfans-heilkenni eða tvíblöðku-ósæðarloku. Hjá síðarnefndu sjúklingunum eru mörkin oft lægri og miðað við 45-50 mm í mesta pvermál. ${ }^{14}$ Peir sjúklingar sem voru undir viðmiðunarmörkum ( $<55 \mathrm{~mm})$ í okkar rannsókn voru allir annaðhvort með einkenni vegna ósæðarlokuleka, höfðu prengsl í lokunni eða voru á leið í kransæðahjáveitu og aðgerð á ósæðargúlpi gerð samtímis. Sjúklingurinn sem hafði stærsta gúlpinn $(10 \mathrm{~cm})$ var með mikinn ósæðarlokuleka og einkenni hjartabilunar en hann hafði sögu um háprýsting en var ekki með pekktan bandvefssjúkdóm.

Aðgerðartækni var mismunandi eftir staðsetningu gúlpsins og hvort gera purfti við ósæðarloku sjúklings eða ekki. Hjá 18 sjúklingum var ósæðinni ekki skipt út heldur var hún einungis sveipuð með ytra stoðneti. Í leiðbeiningum Evrópsku hjartalæknasamtakanna er ekki mælt með pví nema í undantekningartilvikum. ${ }^{14}$ Í okkar rannsókn var ástæðan fyrir sveipun hár aldur sjúklings eða að aðgerðin á ósæðargúlpnum var ekki helsta ábending hjartaaðgerðarinnar. Gúlpurinn hafði pá ekki náð peirri stærð sem talin er vera ábending fyrir umfangsmeiri aðgerð. Samkvæmt leiðbeiningum er mælt með að íhuga aðgerð á ósæð sem er $>45 \mathrm{~mm}$ að vídd ef sjúklingur parf hjartaaðgerð vegna annars hjartasjúkdóms. Meta parf hvert tilvik sérstaklega en ljóst er að hjá eldri sjúklingum getur sveipun komið til greina, sérstaklega ef peir hafa aðra undirliggjandi sjúkdóma sem auka áhættu, sérstaklega við umfangsmiklar og tímafrekari skurðaðgerðir.

Eins og búast mátti við eftir svo stóra aðgerð var heildartíðni fylgikvilla tiltölulega há, en tveir priðju sjúklinga greindust með einhvern fylgikvilla. Par var nýtilkomið gáttatif efst á blaði. Nýtilkomið gáttatif er einnig algengasti minniháttar fylgikvilli eftir aðrar hjartaskurðaðgerðir hér á landi og erlendis, en pá er tíðnin á bilinu $30-50 \%{ }^{20,21}$ Af alvarlegum fylgikvillum reyndust fylgikvillarnir hjartadrep í kringum aðgerð $(15,2 \%)$ og enduraðgerð vegna blæðingar algengastir. Tíðni enduraðgerða vegna blæðingar var $14,3 \%$, sem er hærra en í flestum erlendum rannsóknum par sem hlutfallið er oftast á bilinu 2-10\%. ${ }^{19,22}$ Hárri tíðni enduraðgerða vegna blæðingar hefur áður verið lýst eftir aðrar hjartaskurðaðgerðir á Íslandi, án pess að skýringin á pví sé ljós. ${ }^{23}$ Tíðni heilablóðfalls var hins vegar lág. Heilablóðfall er einn alvarlegasti fylgikvilli pessara aðgerða og helst ekki aðeins í hendur við 30 daga dánartíðni heldur skerðir einnig verulega lífsgæði sjúklinga. Aðeins tveir sjúklingar fengu heilablóðfall. Í báðum tilvikum var um væg tilfelli að ræða par sem einkenni gengu að verulegu leyti til baka á fyrstu mánuðum eftir aðgerð. Annar sjúklingurinn, 83 ára karlmaður, hlaut máttminnkun í hægri hluta líkamans, en hinn, 72 ára gömul kona, sjónsviðsskerðingu. Enginn peirra 8 sjúklinga par sem notast var við blóðrásarstöðvun með kælingu fékk heilaáfall. Erfitt er pó að bera pann árangur saman við erlendar rannsóknir, enda um fáa sjúklinga að ræða. Í öllum 8 aðgerðunum par sem 
beitt var blóðrásarstöðvun var blóði veitt framvirkt upp í heilaæðar (antegrade cerebral perfusion, $A C P$ ) á meðan á blóðrásarstöðvun stóð og pannig reynt að vernda heilann fyrir súrefnisskorti. Ekki hefur enn tekist að sýna með afgerandi hætti hvaða aðgerðartækni veitir bestu heilaverndunina við blóðrásarstöðvun. Framvirk blóðveiting til heila, ásamt meðaldjúpri kælingu, er sú aðferð sem mest hefur verið notuð hér á landi. Nýlegar rannsóknir hafa frekar stutt pá tækni umfram aðrar eldri aðferðir eins og pegar blóði er veitt til heilans í gegnum efri holæð (retrograde cerebral perfusion). ${ }^{17,24}$ Vonir eru pó bundnar við að stór alpjóðleg rannsókn sem nú er í gangi muni varpa ljósi á hvaða aðferð reynist best í pessum aðgerðum. ${ }^{25}$

Dánarhlutfall innan 30 daga frá aðgerð var 1,9\% og er pað sambærileg dánartíðni og í erlendum rannsóknum. ${ }^{18,19}$ Langtímalifun var einnig mjög góð og á pari við stærstu hjartaskurðdeildir erlendis. Pannig var 5 ára lifun 90,3\% í okkar rannsókn en erlendis er hún oftast á bilinu $78-96 \%{ }^{18,19,26-28}$

Langtímalifun var marktækt verri hjá konum en körlum, og hélst munurinn marktækur prátt fyrir að tekið væri tillit til pess að konur voru að meðaltali 3,4 árum eldri en karlar á aðgerðardegi. Erlendar rannsóknir hafa sýnt svipaðar niðurstöður en konur virðast hafa verri langtímahorfur eftir pessar aðgerðir og auk pess hærra 30 daga dánarhlutfall. Skýringin er ekki ljós en petta á bæði við um valaðgerðir og bráðaaðgerðir pegar flysjun verður á ósæðargúlpi. ${ }^{18,29,30}$ Í okkar rannsókn sást pó ekki marktækur munur á 30 daga dánarhlutfalli karla og kvenna, enda ekki við pví að búast par sem aðeins tveir sjúklingar létust innan 30 daga. Báðir voru konur, sem allt eins gæti hafa verið tilviljun.
Styrkur pessarar rannsóknar er að hún nær yfir alla sjúklinga hjá heilli pjóð en allar aðgerðirnar voru framkvæmdar á Landspítalanum. Rannsóknartímabilið tók til 15 ára og aðgerðirnar voru framkvæmdar af tiltölulega fáum skurðlæknum sem allir störfuðu á sömu stofnun. Einnig er styrkur að eftirfylgd sjúklinga var $100 \%$ hvað varðar lifun. Helsti veikleiki rannsóknarinnar er að hún er afturskyggn og klínískar upplýsingar byggja pví á skráningu í sjúkraskrám, sem í sumum tilfellum var ábótavant. Loks voru sjúklingar tiltölulega fáir, eða 105 talsins, sem takmarkar pá tölfræðilegu úrvinnslu sem hægt er að gera á ekki stærri efnivið.

Árangur aðgerða við ósæðargúlp í rishluta ósæðar á Íslandi er góður og svipar til stærri erlendra rannsókna. Árangurinn verður að telja sérstaklega góðan hvað varðar tíðni alvarlegra fylgikvilla eins og heilablóðfalls (1,9\%) og einnig lágrar 30 daga dánartíðni (1,9\%). Tíðni vægari fylgikvilla er hins vegar há eins og gera má ráð fyrir eftir jafn umfangsmikla hjartaaðgerð. Pví er mikilvægt að halda sig við ábendingar pessara stóru aðgerða og taka ekki sjúklinga til aðgerðar par sem ávinningur af aðgerð er óljós. Fyrir sjúklinga með réttar ábendingar er árangur mjög góður og gera má ráð fyrir að yfir 90\% peirra séu á lífi 5 árum eftir aðgerð.

\section{Pakkir}

Pakkir fær Gunnhildur Jóhannsdóttir skrifstofustjóri á skurðdeild Landspítala fyrir aðstoð við öflun sjúkraskráa. Rannsóknin var styrkt af Vísindasjóði Landspítala og Rannsóknarsjóði Háskóla Íslands.

\section{Heimildir}

1. Johnston KW, Rutherford RB, Tilson MD, Shah DM, Hollier L, Stanley JC. Suggested standards for reporting on arterial aneurysms. J Vasc Surg 1991; 13: 452-8.

2. Kuzmik GA, Sang AX, Elefteriades JA. Natural history of thoracic aortic aneurysms. J Vasc Surg 2012; 56: 565-71.

3. Nesi G, Anichini C, Tozzini S, Boddi V, Calamai G, Gori F. Pathology of the thoracic aorta: a morphologic review of 338 surgical specimens over a 7-year period. Cardiovasc Pathol 2009; 18: 134-9.

4. Zhang L, Wang HH. The genetics and pathogenesis of thoracic aortic aneurysm disorder and dissections. Clin Genet 2016; 89: 639-46.

5. Goldfinger JZ, Halperin JL, Marin ML, Stewart AS, Eagle KA, Fuster V. Thoracic Aortic Aneurysm and Dissection. J Am Coll Cardiol 2014; 64: 1725-39.

6. Elefteriades JA, Pomianowski P. Practical genetics of thoracic aortic aneurysm. Prog Cardiovasc Dis 2013; 56: 57-67.

7. Andelfinger G, Loeys B, Dietz H. A Decade of Discovery in the Genetic Understanding of Thoracic Aortic Disease. Can J Cardiol 2016; 32: 13-25.

8. Jondeau G, Boileau C. Familial thoracic aortic aneurysms. Curr Opin Cardiol 2014; 29: 492-8.

9. Chau KH, Elefteriades JA. Natural History of Thoracic Aortic Aneurysms: Size Matters, Plus Moving Beyond Size. Prog Cardiovasc Dis 2013; 56: 74-80.

10. Isselbacher EM. Trends in thoracic aortic aneurysms and dissection: out of the shadows and into the light. Circulation 2014; 130: 2267-8

11. Johansson G, Markström U, Swedenborg J. Ruptured thoracic aortic aneurysms: A study of incidence and mortality rates. J Vasc Surg 1995; 21: 985-8.

12. Geirsson A, Melvinsdóttir IH, Arnórsson P, Mýrdal G, Guðbjartsson T. Árangur aðgerða vegna bráðrar ósæðarflysjunar af gerð A á Íslandi. Læknablaðið 2016; 102: 71-6.
13. Elefteriades JA. Natural history of thoracic aortic aneurysms: indications for surgery, and surgical versus nonsurgical risks. Ann Thorac Surg 2002; 74: 1877-80.

14. Erbel R, Aboyans V, Boileau C, Bossone E, Bartolomeo RD, Eggebrecht $\mathrm{H}$, et al. 2014 ESC Guidelines on the diagnosis and treatment of aortic diseases. Eur Heart J 2014; 35: 2873-926.

15. Nashef SAM, Roques F, Sharples LD, Nilsson J, Smith C, Goldstone AR, et al. EuroSCORE II. Eur J Cardio-Thorac Surg 2012; 41: 734-45.

16. Yan TD, Bannon PG, Bavaria J, Coselli JS, Elefteriades JA, Griepp RB, et al. Consensus on hypothermia in aortic arch surgery. Ann Cardiothorac Surg 2013; 2: 163-8.

17. Griepp RB, Griepp EB. Perfusion and cannulation strategies for neurological protection in aortic arch surgery. Ann Cardiothorac Surg 2013; 2: 159-62.

18. Kallenbach K, Kojic D, Oezsoez M, Bruckner T, Sandrio $\mathrm{S}$, Arif $\mathrm{R}$, et al. Treatment of ascending aortic aneurysms using different surgical techniques: a single-centre experience with 548 patients. Eur J Cardio-Thorac Surg 2013; 44: 337-45.

19. Achneck HE, Rizzo JA, Tranquilli M, Elefteriades JA. Safety of Thoracic Aortic Surgery in the Present Era. Ann Thorac Surg 2007; 84: 1180-5.

20. Helgadottir S, Sigurdsson MI, Ingvarsdottir IL, Arnar DO, Gudbjartsson T. Atrial fibrillation following cardiac surgery: risk analysis and long-term survival. J Cardiothorac Surg 2012; 7: 87.

21. Echahidi N, Pibarot P, O'Hara G, Mathieu P. Mechanisms, Prevention, and Treatment of Atrial Fibrillation After Cardiac Surgery. J Am Coll Cardiol 2008; 51: 793-801.

22. Svensson LG, Pillai ST, Rajeswaran J, Desai MY, Griffin B, Grimm R, et al. Long-term survival, valve durability, and reoperation for 4 aortic root procedures combined with ascending aorta replacement. J Thorac Cardiovasc Surg 2016; 151: 764-71
23. Smárason NV, Sigurjónsson H, Hreinsson K, Arnórsson P, Guðbjartsson T. Enduraðgerðir vegna blæðinga eftir opnar hjartaskurðaðgerðir á Íslandi. Læknablaðið 2009; 95: 567-73.

24. Tian DH, Wan B, Bannon PG, Misfeld M, LeMaire SA Kazui $\mathrm{T}$, et al. A meta-analysis of deep hypothermic circulatory arrest alone versus with adjunctive selective antegrade cerebral perfusion. Ann Cardiothorac Surg 2013; 2: 261-70.

25. Yan TD, Tian DH, LeMaire SA, Misfeld M, Elefteriades JA, Chen EP, et al. The ARCH Projects: design and rationale (IAASSG 001). Eur J Cardio-Thorac Surg 2014 45: 10-6.

26. Higgins J, Lee MK, Co C, Janusz MT. Long-term outcome after thoracic aortic surgery: A population-based study. J Thorac Cardiovasc Surg 2014; 148: 47-52.

27. Etz CD, Homann TM, Silovitz D, Spielvogel D, Bodian CA, Luehr M, et al. Long-Term Survival After the Bentall Procedure in 206 Patients With Bicuspid Aortic Valve. Ann Thor Surg 2007; 84: 1186-94.

28. David TE, Feindel CM, Webb GD, Colman JM, Armstrong S, Maganti M. Long-term results of aortic valve-sparing operations for aortic root aneurysm. J Thorac Cardiovasc Surg 2006; 132: 347-54.

29. Beller CI, Farag M, Wannaku S, Seppelt P, Arif $R$, Ruhparwar A, et al. Gender-specific differences in outcome of ascending aortic aneurysm surgery. PloS One 2015; 10: e0124461.

30. Nienaber CA, Fattori $R$, Mehta RH, Richartz BM, Evangelista A, Petzsch M, et al. Gender-Related Differences in Acute Aortic Dissection. Circulation 2004; 109: 3014-21 


\section{ENGLISH SUMMARY}

\section{Results of operations for ascending aortic aneurysm in Iceland 2000-2014}

Helga Björk Brynjarsdóttir ${ }^{1}$, Inga Hlíf Melvinsdóttir², Tómas Guðbjartsson ${ }^{1,3}$, Arnar Geirsson ${ }^{3}$

Introduction: Thoracic aortic aneurysm (TAA) is an uncommon disease where treatment is complex and associated with significant comorbidity. The main aim of this study was to evaluate the outcomes of operations for TAA in Iceland with emphasis on postoperative complications, 30 day mortality and survival.

Materials and methods: A retrospective study on 105 patients (mean age 60.7 yrs., $69.5 \%$ males) that underwent operations for TAA between 2000 and 2014 in Iceland. Patients with aortic injury or acute aortic dissection were excluded. Clinical information was collected from hospital charts and long-term survival estimated by Kaplan-Meier method. Mean follow-up was 5.7 yrs.

Results: Bicuspid aortic valve was present in 52 patients $(51.0 \%)$ and family history was positive in 10 of the cases $(9.5 \%)$. Every other pati- ent $(50.5 \%)$ was asymptomatic and diagnosed incidentally. The most common procedure was aortic root replacement using biological prosthesis. Two out of three patients had complications, that were regarded as major in $31.4 \%$ of cases, however, stroke was only detected in 2 (1.9\%) patients. Two patients died within 30 days postoperatively (1.9\%). The overall survival at one year was $95.1 \%$; more favorable for males compared to females ( 97.2 vs. $90.4 \%, p=0.0012$, log rank test) and at 5 years $90.3 \%$.

Conclusions: Outcome following surgery for TAA in Iceland is comparable to studies in neighbouring countries. The complications rate is high, however, the stroke rate was low, as was 30 day mortality. Longterm survival is favorable, and is more favorable for males than females.

${ }^{1}$ Faculty of Medicine, University of Iceland, '2Landspitali University Hospital, ${ }^{3}$ Department of Cardiothoracic Surgery, Landspitali University Hospital.

Key words: Thoracic aortic aneurysm, ascending aorta, open heart surgery, complications, operative mortality, survival.

Correspondance: Arnar Geirsson, arnarge@landspitali.is 